UDC 616.006:577.23:577.15

\title{
FUNCTIONAL AND DYNAMIC STATE OF INNER MITOCHONDRIAL MEMBRANE OF SARCOMA 37 IN MICE UNDER ADMINISTRATION OF SODIUM DICHLOROACETATE
}

\author{
S. V. KHYZHNYAK ${ }^{1}$, L. V. SOROKINA², L. I. STEPANOVA ${ }^{3}$, A. A. KAPLIA ${ }^{4}$ \\ ${ }^{1}$ National University of Life and Environmental Sciences of Ukraine, Kyiv; \\ e-mail: khs2014@ukr.net; \\ ${ }^{2}$ R. E. Kavetsky Institute of Experimental Pathology, Oncology and \\ Radiobiology, National Academy of Sciences of Ukraine, Kyiv; \\ ${ }^{3}$ ESC "Institute of Biology", Taras Shevchenko National University of Kyiv, Ukraine; \\ ${ }^{4}$ Palladin Institute of Biochemistry, National Academy of Sciences of Ukraine, Kyiv
}

The activity of enzymes of the respiratory chain and structural-dynamic properties of the inner mitochondrial membrane (IMM) of sarcoma 37 (S37) in mice under sodium dichloroacetate (SDA) administration in a daily dose of $86 \mathrm{mg} / \mathrm{kg}$ of body weight starting from the $2^{\text {nd }}$ day after tumor transplantation were investigated. The dynamic and structural state of the IMM components was determined using the fluorescent probes. With S37 growth the intensification of glycolytic metabolism occurred on the background of suppressed functional capacity of mitochondrial respiratory chain enzymes. The changes of conformational properties of protein molecules and the increase of IMM lipid phase microviscosity were shown. The administration of SDA promotes the decrease of lactate content and the increase of pyruvate dehydrogenase activity in S37. This was accompanied by further suppression of the functional activity of the respiratory chain complexes and $H^{+}$-ATPase coupled with conformational modification of protein molecules and changes of the structural orderliness of the IMM lipid phase, possibly due to intensification of reactive oxygen species generation.

Ke y word s: sarcoma 37, sodium dichloroacetate, glycolysis, inner mitochondrial membrane, respiratory chain enzymes, lipid phase microviscosity, conformational state of the proteins.

$\mathrm{T}$ he inherent property of malignantly transformed cells is the maintaining of their viability by gaining energy mainly using glycolytic pathway even in aerobic conditions [1, 2]. Unlike normal cells, in which about $90 \%$ of the total pool of ATP is produced as a result of oxidative phosphorylation, the level of ATP generation in mitochondria of tumour cells reaches up to $50 \%$ of the overall production of this macroergic compound. Metabolic stress, which arises from lack of oxygen and nutrient substrates in the tumor due to insufficient vascularization is accompanied by accumulation of reactive oxygen species (ROS), that are generated predominantly in mitochondria [2, 3].

The changes of structural properties and functioning of mitochondria caused by the influence of excessive amounts of ROS result in the shift of energy metabolism in the direction of the increased glycolysis intensity [1]. This path is energetically less favourable compared to the oxidation of substrates in mitochondria, but it functions under hypoxic con- ditions and promotes resistance to proapoptotic signals which induction is associated with mitochondria $[1,2]$.

The use of preparations, that can induce the death of neoplastic cells causing metabolic catastrophe state in the tumor by blocking glycolysis, is assumed as a promising means for the therapy of tumors, especially with low dependence on angiogenesis. Inhibition of glycolysis intensity can be achieved by using the substrates analogues of the glycolytic reactions, the inhibitors of the glycolytic enzymes and compounds that can influence the mechanisms of glycolysis regulation [2].

Sodium dichloroacetate (SDA) that selectively inhibits pyruvate dehydrogenase kinase, mostly overexpressed in the tumor cells, belongs to the latter group [4, 5]. This kinase phosphorylates and suppresses the activity of pyruvic dehydrogenase complex, which catalyzes the conversion of pyruvate to acetyl-CoA. In this regard, the use of SDA promotes the activation of pyruvate dehydrogenase 
and further intensification of energy metabolism in mitochondria.

The use of SDA appeared to be effective to slow down the progress of a set of abnormalities associated with mitochondrial dysfunction - arterial hypertension, myocarditis, neurodegenerative diseases, etc. [6-8]. The antitumor action of SDA was demonstrated in vitro against the tumor cells of certain lines with insufficient functioning of mitochondria and bearing SDA molecular target [4-6].

However, the investigation of changes of the mitochondrial membrane properties associated with electron transport chain functioning (and energy metabolism in general) in tumor growth are important for development of new antitumor agents targeting mitochondria or for clarifying the action mechanism of the available agents.

The aim of this study is to examine some parameters that reflect the state of energy metabolism as well as structural and dynamic properties of inner mitochondria membranes of sarcoma 37 in tumor growth kinetics in vivo and evaluate the impact of sodium dichloroacetate on the investigated parameters.

\section{Materials and Methods}

Experimental design. 150 male Balb/c mice 2-2.5 month old weighing 20-25 g were used. The experimental procedures using animals were conducted in accordance with the international requirements of bioethics. Sarcoma 37 (S37) cells $\left(2 \cdot 10^{6}\right.$ cells per mouse) were transplanted into the femoral muscle. S37 belongs to the low-differentiated tumors with polymorphic cells. S37 initially appeared spontaneously as the mammary gland adenocarcinoma and further transformed due to the consequent passaging into sarcoma. S37 is characterized by the aggressive growth and high invasiveness [9]. S37 cells were cultivated in RPMI-1640 (Sigma, USA) with addition of $10 \%$ foetal bovine serum (Sigma, USA), $2 \mathrm{mM}$ L-glutamine and $40 \mu \mathrm{g} / \mathrm{ml}$ gentamicin at $37{ }^{\circ} \mathrm{C}$ in humid atmosphere with $5 \% \mathrm{CO}_{2}$. The viability of cells was determined using $3 \%$ trypan blue.

The animals with transplanted tumors were divided into 2 groups: 1 - untreated mice $(n=60)$; 2 mice with S37 administered intraperitoneally with SDA (daily dose $86 \mathrm{mg} / \mathrm{kg}$ from the 2nd day after transplantation, $n=60$ ).

The growth of S37 was characterized by registration of linear tumor sizes in three dimensions on the $6^{\text {th }}, 11^{\text {th }}, 14^{\text {th }}, 17^{\text {th }}, 20^{\text {th }}, 24^{\text {th }}$ days after transplantation. The tumor volume was calculated.
The euthanasia of animals under the light ester anaesthetic was carried out on the $14^{\text {th }}, 17^{\text {th }}, 20^{\text {th }}$ and $24^{\text {th }}$ days after tumor transplantation.

Isolation of mitochondria and inner mitochondrial membranes. Tumors were washed in physiologic saline, the necrosis sites were removed. Then tumors were homogenized using "BioMix" device (Germany) in $20 \mathrm{mM}$ Tris-HCl buffer (pH 7.4 at $4{ }^{\circ} \mathrm{C}$ ) with $0.32 \mathrm{M}$ sucrose, $2 \mathrm{mM}$ EDTA and cocktail of proteases inhibitors (1 mM phenylmethylsulfonyl fluoride, $50 \mu \mathrm{g} / \mathrm{ml}$ sodium benzamidine and $0.1 \mathrm{mg} / \mathrm{ml}$ soybean trypsin inhibitor). After centrifugation (1500 g, $15 \mathrm{~min}$ ) the supernatant was obtained (S37 homogenate). Then supernatant was centrifuged at $11000 \mathrm{~g}$ for $20 \mathrm{~min}$ to isolate mitochondria. The sediment of mitochondria was resuspended in $30 \mathrm{mM}$ Tris-HCl buffer ( $\mathrm{pH} 7.4$ at $\left.4{ }^{\circ} \mathrm{C}\right)$ containing $2 \mathrm{mM}$ EDTA and $0.25 \mathrm{M}$ sucrose.

In order to isolate the inner mitochondrial membranes (IMM) in the form of submitochondrial particles the mitochondria were frozen with further thawing and sedimented by centrifugation at $25000 \mathrm{~g}$ during $30 \mathrm{~min}$. The sediment contained fraction of IMM, and the supernatant - the outer mitochondrial membranes according to [10]. The purity of the mitochondrial membranes was assayed via marker enzymes analysis (succinate dehydrogenase - E.C. 1.3.99.1 and 5'-nucleotidase - E.C. 3.1.3.5) [11, 12].

The total protein was determined by bromophenol blue assay by Greenberg as described in [13]

Lactate and pyruvate assays. In tumor homogenates the levels of final glycolysis products - lactate and pyruvic acid were determined. The content of lactate was evaluated using the enzymatic method according to [14] in the presence of lactate dehydrogenase - EC 1.1.1.27 (the final activity in the incubation mix - $2 \mathrm{IU} / \mathrm{ml}$, Sigma, USA), 0.05 M NAD in glycine-hydrazine buffer ( $0.4 \mathrm{M}$ hydrazine sulphate, $1 \mathrm{M}$ glycine, 0.2\% EDTA-Na, $\mathrm{pH}$ 9.5) The formation of reduced NAD, which quantity is equivalent to the amount of oxidized lactate, was registered photometrically at the wavelength $340 \mathrm{~nm}$.

The content of pyruvate was determined in the reaction with 2.4-dinitrophenylhydrazine (final concentration $-0.082 \%$ ) in the presence of $\mathrm{NaOH}$ (final concentration $-7.5 \%$ ) that resulted in the formation of red-brown coloured hydrazone which presence was registered at $390 \mathrm{~nm}$ as described in [14].

Pyruvate dehydrogenase assay. The activity of pyruvate dehydrogenase (PDH, E.C. 1.2.4.1) was 
estimated in IMM preparations by the rate of accumulation of reduced NAD in the incubation mix that was registered spectrophotometrically at $340 \mathrm{~nm}$ [15]. The reaction mixture contained $25 \mathrm{mM}$ Tris $\mathrm{HCl}$ (pH 7.4), $50 \mathrm{mM}$ potassium pyruvate, $200 \mu \mathrm{M}$ thiamine pyrophosphate, $1 \mathrm{mM}$ magnesium chloride, $300 \mu \mathrm{M}$ dithiothreitol, $2.5 \mathrm{mM}$ NAD, $10 \mu \mathrm{M}$ EDTA. The reaction was started by adding $0.01 \% \mathrm{CoA}-\mathrm{SH}$. The changes of optical density were registered at $340 \mathrm{~nm}$ every 15 s during 2 min.

The determination of activities of respiratory chain enzymes and $\mathrm{H}^{+}$-ATPase in IMM. The activity of NADH-CoQ-oxidoreductase (NADH-CoQ-OR, E.C. 1.6.99.3) was estimated by spectrophotometrical determination at $550 \mathrm{~nm}$ of the enzyme-catalyzed reduction of cytochrome c by NADH using $2 \mu \mathrm{M}$ rotenone as enzyme inhibitor [16].

The activity of succinate dehydrogenase (SDH, E.C. 1.3.99.1) was evaluated by the determination of the quantity of reduced ferricyanide that was transformed to the potassium ferrocyanide in the reaction with succinate in the presence of enzyme [12]. The absorbance was measured at $420 \mathrm{~nm}$.

The cytochrome oxidase (CO, E.C. 1.9.3.1) activity was estimated by the enzyme-catalyzed oxidation of cytochrome c [17]. The absorbance was registered at $550 \mathrm{~nm}$.

$\mathrm{Mg}^{2+}$-dependent $\mathrm{H}^{+}$-ATPase activity in IMM was determined according to [18] with oligomycin $(5 \mu \mathrm{g} / \mathrm{ml})$ as enzyme inhibitor. The values of the enzymes activity were normalized to sample protein concentration.

Tryptophan fluorescence and conformational properties of protein molecules. The intensity of the fluorescence displayed by tryptophan residues (Trp) in the proteins of S37 IMM was measured in $20 \mathrm{mM}$ phosphate buffer saline ( $\mathrm{pH} 7.4$ at $25^{\circ} \mathrm{C}$ ) at $338 \mathrm{~nm}$ as described in [19], the excitation wavelength was $296 \mathrm{~nm}$. Acrylamide was used for the quenching of Trp fluorescence of IMM proteins. To the membrane suspension $(0.1 \mathrm{mg}$ of protein $/ \mathrm{ml})$ the $1 \mathrm{M}$ acrylamide was added up to the final concentration $0.4 \mathrm{M}$. The excitation wavelength was fixed at $296 \mathrm{~nm}$ in order to eliminate the contribution of the tyrosine residues, and the emission spectra were recorded between $305 \mathrm{~nm}$ and $400 \mathrm{~nm}$. Excitation and emission slits were set at 5 and $10 \mathrm{~mm}$, respectively. The collisional quenching constant and the accessibility of fluorophore were monitored by analyzing the quenching data using the modified Stern-Volmer equation for heterogeneously emitting systems, assuming that all the fluorophores were independent and equally absorbing.

$$
\frac{F_{0}}{F_{0}-F}=\frac{1}{f_{\alpha} K_{q}[Q]}+\frac{1}{f_{\alpha}},
$$

where $f_{\alpha}$ is the maximum fraction of the fluorophore accessible to the quencher at concentration $[Q], F_{0}-F$ is the difference in the native fluorescence and that after quenching, $K_{\mathrm{q}}$ is the collisional quenching constant, and $[Q]$ is the acrylamide concentration. $1 / f_{\alpha}$ is the intercept from a plot of $F_{0} /\left(F_{0}-F\right)$ vs. $1 /[Q]$ for a range of concentrations of quencher and $\mathrm{Kq}$, that reflects the intramolecular dynamics of protein molecules, is derived from the intercept/slope.

Annular/bulk lipid fluidity. A fluorescent method based on radiationless energy transfer from Trp of IMM proteins to pyrene and pyrene monomer/excimer formation described in [19] was used to determine the fluidity of the annular lipids and bulk lipids of IMM, respectively. The pyrene excimer/monomer fluorescence intensities ratios, when pyrene was excited through energy transfer from $\operatorname{Trp}\left(\lambda_{\text {ex }}=280 \mathrm{~nm}\right)$ and when pyrene was excited at its own excitation wavelength $\left(\lambda_{\text {ex }}=335 \mathrm{~nm}\right)$, were used to calculate the fluidity of annular and bulk lipids, respectively. Band pass slits were $10 \mathrm{~nm}$ on excitation and $5 \mathrm{~nm}$ on emission. Pyrene emission spectra were recorded at $\lambda_{\text {em }}=390 \mathrm{~nm}$ (monomer) and $\lambda_{\text {em }}=470 \mathrm{~nm}$ (excimer). The samples of IMM (0.1 $\mathrm{mg}$ of protein $/ \mathrm{ml}$ ) were suspended in buffer (100 mM KCl, 5 mM Tris-HCl, pH 7.4). Pyrene (final concentration $-5 \mu \mathrm{M}$ ) was added to the samples. The fluidity of the bulk and annular lipid fraction of IMM was considered proportional to the suitable ratio $\mathrm{N}=\mathrm{Fe} / \mathrm{Fm}$, where $\mathrm{Fe}$ and $\mathrm{Fm}$ are the fluorescence of pyrene excimer and monomer, respectively.

Properties of the superficial layer of IMM. The state of the IMM surface was evaluated using the fluorescent probe 1-anilinonaphthalene-8-sulfonic acid (ANS) that binds with the surface of membrane as described in [19]. The intensity of ANS fluorescence bound with IMM residues was measured in $20 \mathrm{mM}$ phosphate buffer saline ( $\mathrm{pH} 7.4$ at $25^{\circ} \mathrm{C}$ ) at $470 \mathrm{~nm}$, the excitation wavelength was $270 \mathrm{~nm}$.

Resonance energy transfer. The non-radiation energy transfer between the tryptophanyl residues of membrane proteins $(0.1 \mathrm{mg}$ of protein/ml) and pyrene $(5-20 \mu \mathrm{M})$ was measured by quenching of the tryptophan fluorescence at $338 \mathrm{~nm}$ after excitation 
at $296 \mathrm{~nm}$ as described in [19]. The total volume of added pyrene did not exceed $1 \%$ of the initial sample volume.

Background fluorescence of each pyrene concentration was recorded similarly in the absence of IMM preparations and subtracted from the corresponding sample spectra. The efficiency of energy transfer for the donor-acceptor pairs was calculated from quenching donor fluorescence by acceptor according to the relationship: $\mathrm{E}=1-\left(F / F_{0}\right)$.

Statistical analysis. Statistical analysis of the results and curve fitting were performed by means of Origin 8.0 for Windows. Significant statistical differences between two groups were evaluated using Student's $t$-test $(P \leq 0.05)$. The data are given as means $\pm \mathrm{SEM}$.

\section{Results and Discussion}

Sarcoma 37 growth kinetics. The kinetics of S37 growth shows three-step pattern. The initial lag phase of S37 growth kinetics was discriminated up to 11th day after intramuscular transplantation of S37 cells into the thigh of Balb/c mice. Then the volume of tumour increased from $0.44 \pm 0.07 \mathrm{~cm}^{3}$ on the 11th day to $1.39 \pm 0.13 \mathrm{~cm}^{3}$ on the $17^{\text {th }}$ day. The rate of S37 size increased 4.03 times $(P \leq 0.05)$ in exponential phase (period from the $11^{\text {th }}$ to the $17^{\text {th }}$ day) compared to the initial period. Since the $18^{\text {th }}$ day up to the $24^{\text {th }}$ day of the experiment the rate of S37 growth decreased on the average by $49.3 \%$ $(P \leq 0.05)$ in comparison with the preceding interval that points out the existence of stationary phase of S37 growth that covered the period from the $18^{\text {th }}$ to the 24th day after tumor cells transplantation [20].

The administration of SDA to the animals with transplanted S37 in the daily dose of $86 \mathrm{mg} / \mathrm{kg}$ led to the retardation of S37 growth by $31.5 \%(P \leq 0.05)$ in the period covering the $11^{\text {th }}-17^{\text {th }}$ days and by $52.8 \%$ $(P \leq 0.05)$ in the period of stationary tumor growth from the $18^{\text {th }}$ to the $24^{\text {th }}$ day after tumor transplantation as compared with SDA-untreated mice [20].

Final glycolytic products and PDH activity. It was shown that lactate content increased on the $20^{\text {th }}$ and $24^{\text {th }}$ days of S37 growth on the average by $22 \%$ as compared with the $14^{\text {th }}$ and the $17^{\text {th }}$ days of tumor growth. The administration of SDA to tumor-bearing animals led to the decreased lactate levels in S37 on the $17^{\text {th }}, 20^{\text {th }}$ and $24^{\text {th }}$ days by $27-28 \%$ in comparison with the parameter values for S37 of SDA-untreated mice (Table 1) in accordance with [21].

The level of the other final product of glycolysis - pyruvate was relatively stable in S37 during all the time of observation. In the tumors of SDAtreated mice the content of pyruvate decreased, however these changes were significant only on the $14^{\text {th }}$ day of tumor growth (Table 1 ).

The activity of pyruvate dehydrogenase (PDH) that transforms pyruvate to acetyl-CoA and provides the formation of NADH changed slightly with the S37 growth (Table 1). Under the administration of SDA to the mice with S37 the enzyme activity in tumor increased on the $14^{\text {th }}, 17^{\text {th }}$ day and $20^{\text {th }}$ days of tumor growth by 42, 40 and 36\%, respectively, as compared with the value of PDH activity in S37 of SDA-untreated mice. On the $24^{\text {th }}$ day of the experiment under the treatment of SDA the PDH activity increased in tumors of mice by $30 \%$ relative to the value for SDA-untreated mice and by $60 \%$ in comparison with the activity for SDA-treated mice on the $14^{\text {th }}$ day of S37 growth.

Activities of respiratory chain enzymes and $\mathrm{H}^{+}$ATPase. It was found that the progressive decrease

Ta b le 1. The content of final glycolysis products and pyruvate dehydrogenase (PDH) activity in sarcoma 37 during tumor growth and under influence of sodium dichloracetate, $M \pm m$

\begin{tabular}{lc|c|c|c|c}
\hline & & \multicolumn{4}{|c}{ Day of S37 growth } \\
\cline { 3 - 6 } & & \multicolumn{1}{|c}{14} & \multicolumn{1}{c}{17} & \multicolumn{1}{c}{20} & 24 \\
\hline Lactate, nmol/mg & 1 & $5.13 \pm 0.33$ & $5.57 \pm 0.51$ & $6.26 \pm 0.38^{*}$ & $6.82 \pm 0.43^{*}$ \\
& 2 & $4.82 \pm 0.32$ & $4.01 \pm 0.21^{* * * *}$ & $4.52 \pm 0.30^{* *}$ & $5.01 \pm 0.44^{* *}$ \\
Pyruvate, nmol/mg & 1 & $80.1 \pm 4.4$ & $69.2 \pm 6.1$ & $86.1 \pm 7.4$ & - \\
& 2 & $68.2 \pm 4.7^{* *}$ & $63.1 \pm 5.4$ & $72.1 \pm 6.4$ & - \\
PDH, nmol NADH/mg.min & 1 & $0.99 \pm 0.08$ & $1.15 \pm 0.11$ & $1.22 \pm 0.18$ & $1.73 \pm 0.14^{*}$ \\
& 2 & $1.41 \pm 0.13^{* *}$ & $1.61 \pm 0.12^{* *}$ & $1.66 \pm 0.16^{* *}$ & $2.25 \pm 0.33^{* * * *}$ \\
\hline
\end{tabular}

Note: 1 - SDA-untreated animals $(n=60) ; 2$ - SDA-treated animals $(n=60)$. Significant differences $(P \leq 0.05): *-v s$. 14 -th day, ${ }^{* *}-$ vs. corresponding values for SDA-untreated mice. 
of succinate dehydrogenase (SDH) activity of IMM occured under tumor growth (Table 2). On the $17^{\text {th }}$ and on the $20^{\text {th }}$ days of S37 growth the activity of SDH was reduced by $34 \%$, and on the $24^{\text {th }}$ day it decreased by $38 \%$ as compared with this parameter on the $14^{\text {th }}$ day of observation.

With S37 growth the activity of cytochrome oxidase (CO) - the IV complex of respiratory chain decreased in IMM on the $17^{\text {th }}, 20^{\text {th }}$ and $24^{\text {th }}$ days by 24, 35 and 36\%, respectively, compared with the CO activity value on the $14^{\text {th }}$ day of S37 growth (Table 2). In the kinetics of S37 growth in SDA-treated mice the reduction of $\mathrm{CO}$ activity was observed on the $17^{\text {th }}, 20^{\text {th }}$ and $24^{\text {th }}$ days by 25,33 and $36 \%$, respectively, in comparison with the enzyme activity on the $14^{\text {th }}$ day of S37 growth.

The administration of SDA to animals with tumors caused the decrease of SDH activity in S37 on the $14^{\text {th }}, 17^{\text {th }}, 20^{\text {th }}$ and $24^{\text {th }}$ days by $39,24,19$ and $18 \%$, respectively, compared to the S37 of untreated mice. Under treatment of S37-bearing mice with SDA CO activity in S37 reduced on the $14^{\text {th }}, 17^{\text {th }}$, $20^{\text {th }}$ and $24^{\text {th }}$ days by $20-26 \%$ compared with the corresponding values for SDA-untreated mice (Table 2).

It was also found that in IMM from S37 of SDA-treated mice the activity of NADH-KoQoxidoreductase decreased on the average by $51 \%$ $(P \leq 0.05)$ as compared with the activity of this enzyme in tumors of untreated mice (for example on the $20^{\text {th }}$ day of S37 growth from $18.89 \pm 4.40$ to $9.25 \pm 1.30 \mu \mathrm{mol} \mathrm{CoQH} / \mathrm{min} \cdot \mathrm{mg}$ ).

The inhibition of $\mathrm{H}^{+}$-ATPase activity on the average by $21 \%$ (Table 2), the enzyme which uses proton transmembrane electrochemical gradient energy generated by respiratory chain complexes for
ADP phosphorylation, indicates the decrease of the phosphorylation ability of the IMM from S37 of SDA-treated mice. The inhibition of the respiratory chain enzymes of S37 cells, in particular $\mathrm{H}^{+}$-ATPase, may occur due to conformational changes of the enzyme structure induced by ROS, which generation increases after SDA treatment [22]. The products of lipid peroxidation in mitochondrial membrane are potential uncoupling factors of oxidation and phosphorylation.

Tryptophan fluorescence. At the estimation of the conformational state of protein molecules in IMM it was found that the intensity of fluorescence of tryptophanyl residues (FTR) reduced on the $17^{\text {th }}, 20^{\text {th }}$ and $24^{\text {th }}$ days of S37 growth by 20,34 and $40 \%$, respectively, compared with the value of this parameter on the 14th day (Table 3). A similar tendency of FTR decrease was observed with the growth of S37 in SDA-treated mice. On the $17^{\text {th }}$ day of S37 growth this decrease was $23 \%$, and on the $20^{\text {th }}$ and $24^{\text {th }}$ days it reached 28 and $37 \%$, respectively, compared with FTR value for IMM of S37 on the $14^{\text {th }}$ day.

The administration of SDA to the tumorbearing mice promoted the decrease of the FTR value for S37 IMM at all terms of observation. On the $14^{\text {th }}$ day of S37 growth under SDA treatment the FTR reduced by $32 \%$, and on the $17^{\text {th }}, 20^{\text {th }}$ and $24^{\text {th }}$ days - by 36, 27 and 29\%, respectively, compared with the values for SDA-untreated mice (Table 3).

The analysis of the Stern-Volmer plots for the quenching by acrylamide of tryptophanyl fluorescence in the IMM from S37 (Fig. 1) allowed determining the value of the Stern-Volmer quenching constant $\left(K_{q}\right)$ that characterizes the intermolecular

Ta b le 2. The parameters of functional activity of respiratory chain in mitochondria of sarcoma 37 during tumor growth and under influence of sodium dichloracetate, $M \pm m$

\begin{tabular}{|c|c|c|c|c|c|}
\hline & \multicolumn{4}{|c|}{ Day of S37 growth } \\
\hline & & 14 & 17 & 20 & 24 \\
\hline \multirow{2}{*}{$\begin{array}{l}\mathrm{SDH}, \mu \mathrm{mol} \mathrm{K}_{3}\left[\mathrm{Fe}(\mathrm{CN})_{6}\right] / \\
\mathrm{mg} \cdot \mathrm{min}\end{array}$} & 1 & $375.9 \pm 30.9$ & $246.1 \pm 21.2^{*}$ & $249.5 \pm 25.0^{*}$ & $232.1 \pm 16.3^{*}$ \\
\hline & 2 & $229.3 \pm 14.1^{* *}$ & $187.2 \pm 12.3^{* * * *}$ & $203.1 \pm 21.0$ & $190.5 \pm 10.9^{* * * *}$ \\
\hline \multirow{2}{*}{$\begin{array}{l}\mathrm{CO}, \mu \mathrm{mol} \text { of oxidized } \\
\text { cyt. } c / \mathrm{mg} \cdot \mathrm{min}\end{array}$} & 1 & $10.8 \pm 0.9$ & $8.2 \pm 0.7^{*}$ & $7.0 \pm 0.6^{*}$ & $6.9 \pm 0.7^{*}$ \\
\hline & 2 & $8.1 \pm 0.6^{* *}$ & $6.1 \pm 0.5^{* * * *}$ & $5.4 \pm 0.4^{* * * *}$ & $5.5 \pm 0.7^{*}$ \\
\hline \multirow{2}{*}{$\begin{array}{l}\mathrm{H}^{+} \text {-ATPase, } \mu \text { moles } \mathrm{P}_{\mathrm{i}} / \mathrm{mg} \\
\text { protein'min }\end{array}$} & 1 & - & $0.056 \pm 0.004$ & $0.051 \pm 0.004$ & $0.047 \pm 0.004$ \\
\hline & 2 & - & $0.045 \pm 0.003^{* *}$ & $0.039 \pm 0.003^{* *}$ & $0.037 \pm 0.002 * *$ \\
\hline
\end{tabular}

Note: 1 - SDA-untreated animals $(n=60) ; 2$ - SDA-treated animals $(n=60)$. SDH- succinate dehydrogenase. CO - cytochrome oxidase. Significant differences $(P \leq 0.05):{ }^{*}-$ vs. 14 -th day, ${ }^{*} *-$ vs. corresponding values for SDA-untreated mice. 
Ta ble 3. The parameters of structural state of protein component of IMM of sarcoma 37 during the tumor growth and under sodium dichloracetate influence, $M \pm m$

\begin{tabular}{|c|c|c|c|c|c|}
\hline & & \multicolumn{4}{|c|}{ Day of S37 growth } \\
\hline & & 14 & 17 & 20 & 24 \\
\hline \multirow[t]{2}{*}{ FTR, RFU } & 1 & $215.7 \pm 16.1$ & $172.5 \pm 11.0^{*}$ & $142.7 \pm 12.1^{*}$ & $128.7 \pm 11.1^{*}$ \\
\hline & 2 & $144.0 \pm 10.0 * *$ & $110.6 \pm 10.1^{* * * *}$ & $103.9 \pm 9.5^{*, * *}$ & $91.4 \pm 8.2^{* * * *}$ \\
\hline \multirow{2}{*}{$K_{\mathrm{q}}$} & 1 & $2.12 \pm 0.13$ & $1.71 \pm 0.15^{*}$ & $1.69 \pm 0.14^{*}$ & $1.61 \pm 0.14 *$ \\
\hline & 2 & $1.72 \pm 0.14^{* *}$ & $1.32 \pm 0.12^{*, * *}$ & $1.31 \pm 0.12^{*, * *}$ & $1.09 \pm 0.09^{* * * *}$ \\
\hline \multirow[t]{2}{*}{$f_{\alpha}$} & 1 & $0.53 \pm 0.04$ & $0.49 \pm 0.03$ & $0.52 \pm 0.04$ & $0.58 \pm 0.06$ \\
\hline & 2 & $0.54 \pm 0.03$ & $0.50 \pm 0.03$ & $0.48 \pm 0.03$ & $0.55 \pm 0.05$ \\
\hline
\end{tabular}

Note: 1 - SDA-untreated animals $(n=60) ; 2$ - SDA-treated animals $(n=60)$. FTR - fluorescence of Trp residues, RFU relative fluorescence units, $K_{\mathrm{q}}$ - Stern-Volmer constant, $f_{\alpha}$ - accessibility of Trp residues for quencher. Significant differences $(P \leq 0.05): *-$ vs. 14 -th day, ${ }^{* *}-$ vs. corresponding values for SDA-untreated mice.

dynamics of protein molecules [19] and the accessibility of Trp residues to quencher $\left(f_{\alpha}\right)$.

The gradual decrease of the $K_{\mathrm{q}}$ value was observed for the proteins of IMM from S37 with the tumor growth. On the $17^{\text {th }}, 20^{\text {th }}$ and $24^{\text {th }}$ days of tumor growth the $K_{\mathrm{q}}$ value was on the average lower by 19 , 20 and 24\%, respectively, compared with the value for IMM from S37 of these mice on the $14^{\text {th }}$ day. With the growth of S37 in SDA-treated mice the value of this constant for the proteins of S37 IMM decreased. On the $17^{\text {th }}, 20^{\text {th }}$ and $20^{\text {th }}$ days of S37 growth the decrement of $K_{\mathrm{q}}$ value was 23, 24 and 37\%, respectively, in comparison with the $14^{\text {th }}$ day (Table 3 ).

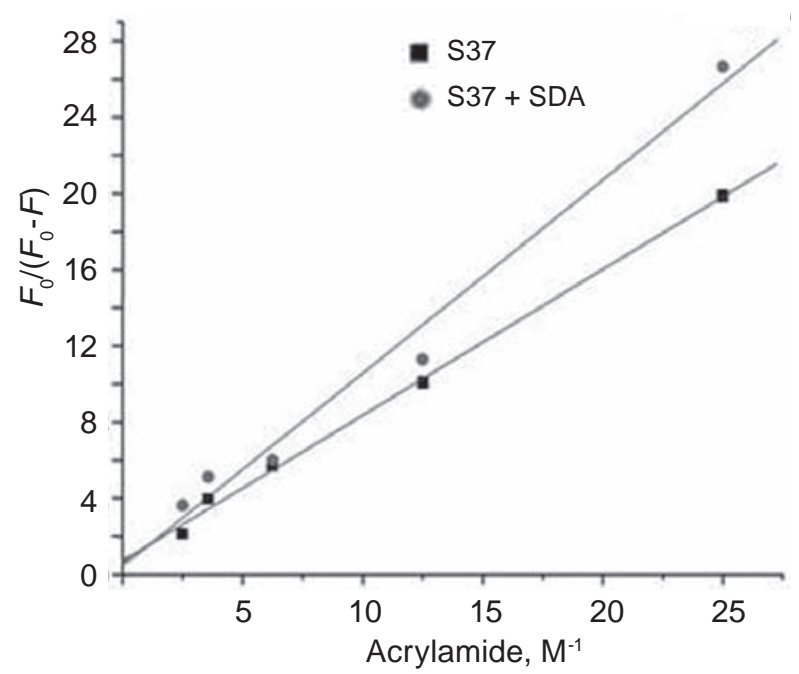

Fig. 1. The typical Stern-Volmer plot obtained for the inner mitochondria membrane preparations of sarcoma 37 (S37). $F_{0}$ is the value of native fluorescence and $F$ is the fluorescence after quenching
On the $14^{\text {th }}, 17^{\text {th }}, 20^{\text {th }}$ and $24^{\text {th }}$ days of S37 growth the administration of SDA caused the reduction of $K_{\mathrm{q}}$ value by 19, 23, 24 and 32\% as compared with the value for IMM from tumors of untreated mice.

The insignificant fluctuations of the value of accessibility of tryptophanyl residues to quencher in the kinetics of S37 growth and under influence of SDA were observed.

Microviscosity of membrane lipids. The differences in the fluorescence spectra of IMM of S37 in the presence of pyrene and without the probe (Fig. 2) were demonstrated on the different terms of tumor growth in SDA-treated and SDA-untreated mice. The degree of IMM lipid phase microviscosity was estimated analyzing the rate of excimerization (the excimer/monomer fluorescence ratio - Ie/Im) of pyrene that distributes throughout the hydrophobic part of membrane.

With the growth of S37 in SDA-untreated and SDA-treated mice the significant changes of the degree of microviscosity of total lipid phase of tumor IMM and of lipids that directly contact with protein molecules in S37 IMM were not observed (Table 4).

The administration of SDA led to the increase of the rate of pyrene excimerization in total lipid phase (detected using the emission wavelength of $335 \mathrm{~nm}$ ) of IMM from S37 on the $17^{\text {th }}$ and $24^{\text {th }}$ days of S37 growth by 23 and 31\%, respectively, as compared to SDA-untreated mice. On the $14^{\text {th }}$ and $20^{\text {th }}$ days the insignificant decrease of total lipid phase microviscosity was found for IMM from S37 of SDA-treated mice in comparison with the values for untreated animals (Table 4). 

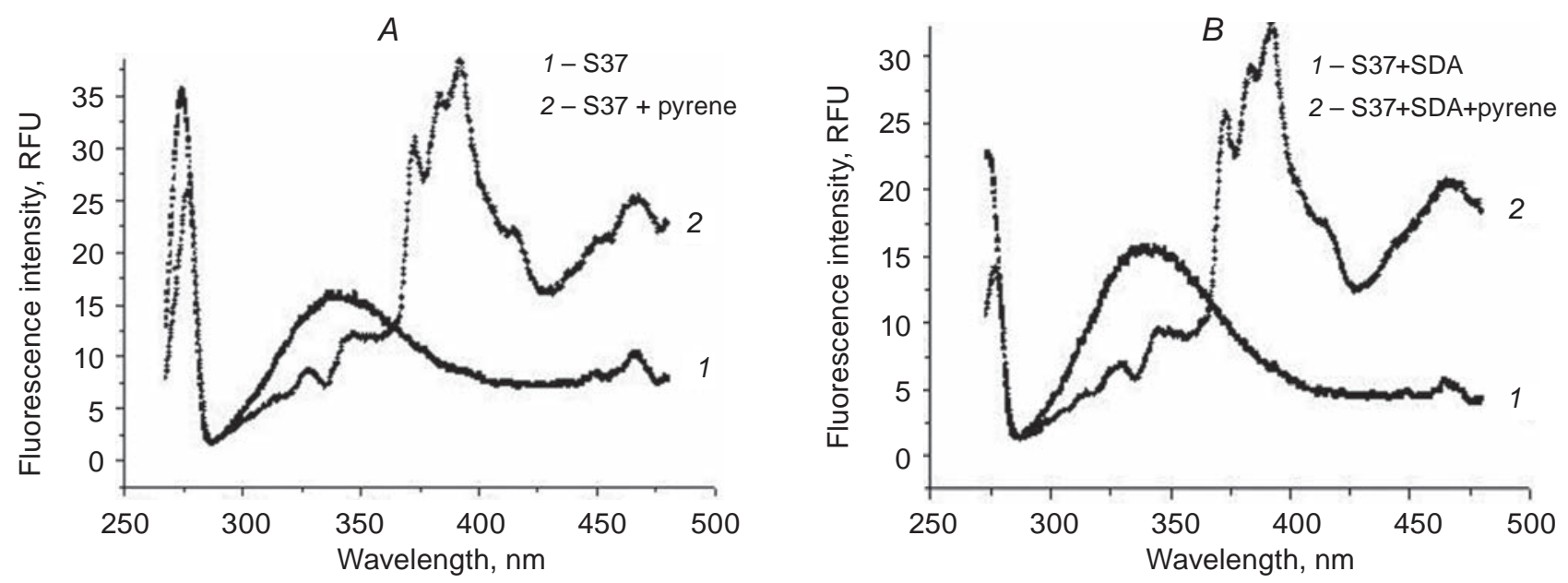

Fig. 2. The typical fluorescence spectra of IMM of S37 in the presence of fluorescent hydrophobic probe pyrene: A - IMM isolated from S37 (the $20^{\text {th }}$ day of tumor growth), B - IMM isolated from S37 of mice treated with $S D A$ (the $20^{\text {th }}$ day of tumor growth)

Ta ble 4. Pyrene excimerization in bulk lipid phase (N335) and in annular lipids phase (N280) of IMM of sarcoma 37 during tumor growth and under sodium dichloracetate influence, $M \pm m$

\begin{tabular}{|c|c|c|c|c|c|}
\hline & & \multicolumn{4}{|c|}{ Day of S37 growth } \\
\hline & & 14 & 17 & 20 & 24 \\
\hline \multirow[t]{2}{*}{ N335 } & 1 & $0.98 \pm 0.06$ & $0.96 \pm 0.07$ & $1.14 \pm 0.10$ & $0.94 \pm 0.08$ \\
\hline & 2 & $1.11 \pm 0.09$ & $1.18 \pm 0.11^{* *}$ & $1.30 \pm 0.11$ & $1.23 \pm 0.10^{* *}$ \\
\hline \multirow[t]{2}{*}{ N280 } & 1 & $0.73 \pm 0.05$ & $0.84 \pm 0.06$ & $0.90 \pm 0.07$ & $0.91 \pm 0.06$ \\
\hline & 2 & $0.94 \pm 0.08 *$ & $1.03 \pm 0.09 *$ & $0.95 \pm 0.08$ & $0.86 \pm 0.05$ \\
\hline
\end{tabular}

Note: 1 - SDA-untreated animals $(n=60) ; 2$ - SDA-treated animals $(n=60)$. Significant differences $(P \leq 0.05): *-v s$. 14-th day, ${ }^{* *}-$ vs. corresponding values for SDA-untreated mice.

The use of SDA has led to a significant increase of the rate of pyrene excimerization in the phase of annular lipids only on the $14^{\text {th }}$ and $17^{\text {th }}$ days of tumor growth by 29 and 23\%, respectively, in comparison with the values for S37 of SDA-untreated mice (Table 4).

Spatial organization of protein-lipid complexes. Since the structural and functional integrity of biological membranes is based on the protein-lipid interactions, the evaluation of some aspects of the spatial organization of protein-lipid complexes in the inner mitochondrial membrane of S37 cells (concretely the rate of the immersion of membrane protein molecules into the lipid bilayer) was performed using the resonance energy transfer in the pair “tryptophanyl residues-pyrene” (Table 5, Fig. 2).

The obtained results indicated the existence of differences in the $\left(F_{0}-F\right) / F_{0}$ value between the IMM of S37 at the exponential and stationary phases of tumor growth. The (Fo-F)/Fo value decreased on the $20^{\text {th }}$ and $24^{\text {th }}$ days of tumor growth on the average by $23 \%$ compared with the $14^{\text {th }}$ and $17^{\text {th }}$ days of S37 growth.

Under the treatment of SDA the similar character of $\left(F_{0}-F\right) / F_{0}$ value reduction in terms of stationary phase was determined, it comprised $27 \%$ compared with the value on the $14^{\text {th }}$ and $17^{\text {th }}$ days of S37 growth.

It was found that the level of the fluorescence of ANS bound to the surface of IMM (Fig. 2) of S37 on the $20^{\text {th }}$ day of tumour growth decreased by $18 \%$ compared to the value of this parameter on the $14^{\text {th }}$ and $17^{\text {th }}$ days. For IMM from S37 of SDA-treated mice the decrease of ANS fluorescence by $21 \%$ was observed on the $17^{\text {th }}$ and $20^{\text {th }}$ days of S37 growth compared to the $14^{\text {th }}$ day (Table 5).

The treatment of tumor-bearing animals with SDA led to the average decrease by $20 \%(P \leq 0.05)$ 
Table 5. The value of $\left(F_{0}-F\right) / F_{0}$ for "tryptophanyl residues-pyrene" and the fluorescence of ANS bound with the surface of IMM of sarcoma 37 under sodium dichloracetate influence, $M \pm m$

\begin{tabular}{lc|c|c|c|c}
\hline & \multicolumn{4}{|c}{ Day of S37 growth } \\
\cline { 3 - 6 } & 1 & $0.44 \pm 0.04$ & $0.50 \pm 0.05$ & $0.37 \pm 0.03$ & $0.35 \pm 0.04^{*}$ \\
$\left(F_{0}-F\right) / F_{0}$ & 2 & $0.48 \pm 0.04$ & $0.49 \pm 0.04$ & $0.36 \pm 0.03$ & $0.36 \pm 0.04$ \\
$\mathrm{~F}_{\text {ANS }}, \mathrm{RFU}$ & 1 & $612 \pm 50$ & $617 \pm 51$ & $502 \pm 45^{*}$ & - \\
& 2 & $534 \pm 50^{* *}$ & $416 \pm 40^{* *}$ & $438 \pm 40$ & - \\
\hline
\end{tabular}

Note: 1 - SDA-untreated animals; 2 - SDA-treated animals. Significant differences $(P \leq 0.05):{ }^{*}-$ vs. 14 -th day, ${ }^{* *}$ - vs. corresponding values for SDA-untreated mice. RFU - relative fluorescence units.

of the fluorescence of ANS bound with the IMM surface from S37.

Under the use of SDA in the total dose $1.6 \mathrm{~g} / \mathrm{kg}$ the significant changes of serum blood parameters that characterize the state of the liver (the activity of alanine aminotransferase, aspartate aminotransferase, gammaglutamyl transpeptidase, alkaline phosphatase, the content of bilirubin), kidney (the content of urea and creatinin) and lipid metabolism (the content of total lipids, triglycerides, cholesterol) were not detected [20].

The obtained results on the toxicity of SDA in the total dose on the $20^{\text {th }}$ day of SDA intraperitoneal administration in relation to the liver, kidney and on the influence of this substance on the lipid metabolism are in accordance with the data of the studies described in $[23,24]$ that failed to show any significant toxicity of SDA in the doses recommended for therapeutical use (30-100 mg/kg per day).

The results presented in [23] point out that dichloroacetate inhibits its own metabolism by an unknown mechanism, and although the half-life of SDA obtained with the first dose is less than one hour, then this half-life increases to several hours with subsequent doses. There is a plateau of this effect and both SDA serum levels and SDA metabolites levels do not continue to rise with chronic use of this agent $[4,23]$. These data give the possibility to investigate the SDA effects on the different terms of S37 growth assuming the maintaining of the plateau levels of SDA in the organism of tumor-bearing mice.

The administration of SDA to animals in the daily dose $86 \mathrm{mg} / \mathrm{kg}$ facilitates the inhibition of S37 growth from beginning of exponential growth phase [20]. The obtained results correspond to the evidences about the ability of this preparation to cause the death of tumor cells $[4,5]$.
It was established that the level of lactate increased on the stationary phase of tumor growth that could be considered as the consequence of enhanced glycolytic processes in the tumor that grows due to the insufficient oxygen and nutrient substrates supply associated with a less quick (in comparison with neoplastic cell proliferation) growth of blood vessels [25]. Lactate belongs to the paracrine regulators of tumor growth since it is excreted into the intercellular space and influences the proliferative potential, the energy metabolism of surrounding cells and facilitates the expression of HIF1 in tumor cells.

The malignancies with the high rate of proliferation to which belongs S37 are characterized by the more intensive aerobic glycolysis in the tumor cells [26]. The predominance of this metabolic pathway in most types of cancer cells is the result of mitochondrial dysfunction due to hyperpolarization of membranes and decrease of the content of active enzymes within the respiratory chain [27]. The shift of energy metabolism towards the predominance of aerobic glycolysis is one of the regulatory mechanisms mediating the formation of resistance to apoptotic signals and survival of tumor cells [4].

The ability of SDA to reduce the content of lactate in S37 at all terms of observation could be explained with the mechanism of the action of this compound. SDA is the selective inhibitor of the PDH kinase, and the effect of this compound leads to activation of pyruvate dehydrogenase which transforms pyruvate to acetyl-CoA. The consequence of this enzyme activation could be a shift of equilibrium of the reaction catalyzed by lactate dehydrogenase in the direction of prevailing formation of pyruvate which utilization is provided by activated PDH $[4,6]$. The obtained results are also in accordance with the data of the authors of [8], who established the ability of SDA to facilitate the decrease of the content 
of lactate and pyruvate in the cerebrospinal fluid of patients with mitochondrial encephalomyelopathy.

The relatively stable content of pyruvate is maintained in S37 during the tumor growth on the background of increased content of lactate. The tendency to the decrease of pyruvate content in S37 of SDA-treated mice (in comparison with untreated mice) could be assumed to be a result of more intensive PDH-provided utilization of pyruvate generated from the lactate. The increase of PDH activity found in S37 of SDA-treated mice is consistent with the information about the mechanism of SDA action on the cells with activated PDH kinase, including malignant cells. Dichloroacetate inhibits specifically this kinase, reduces the level of phosphorylated inactive PDH $[4,6,8]$.

The demonstrated in our study decrease of SDH activity in S37 with the tumor growth is in agreement with the data presented in [28], where the specific dysfunction of electron transfer ability of complex II of respiratory chain is considered as one of the primary events in the metabolic reprogramming of the tumour cell even on the early stages of tumor growth. As the causes of this dysfunction the processes of oxidative modification of functionally active groups of the enzyme or changes in the regulation of SDH gene expression in malignant cells could be assumed.

In conditions of oxygen deficiency and lack of nutrients in the microenvironment of tumor cells the transcription factor HIF-1 (hypoxia-inducible factor-1) becomes activated, and in turn it activates the enzymes of glycolysis, stimulates the expression of antiapoptotic proteins and anti-angiogenic factors [4]. One of the consequences of HIF-1 $\alpha$ activation is the inhibition of mitochondrial succinate dehydrogenase [29]. Mutations in the gene encoding SDH are crucial for the formation of tumor phenotype and determine the genetic predisposition to cancer; therefore, SDH could be attributed to the proteins with the functions of tumor suppressor. Reduced activity of SDH in mitochondrial membrane correlates with a greater degree of tumor aggressiveness [30, 31].

The decrease of CO activity from the $17^{\text {th }}$ day of tumor growth as compared with the 14th day can be associated with the modulation of the expression of CO gene by HIF-1 that results in the changes of subunit composition of complex as a consequence of proteolysis of the subunits by activated protease LON [32]. This causes the abnormal assembly of CO due to defective expression of assembly factors $\mathrm{SCO}_{1}$ and $\mathrm{SCO}_{2}$. As the result the deficiency of functionally active $\mathrm{CO}$ appears in tumor cells. The inhibition of the activity of the enzymes localized in the respiratory chain of mitochondria of S37 cells correlates with the intensification of glycolytic metabolism that is manifested in the increase of lactate content in terms of stationary growth of S37. Taking into account the data presented in [2] it could be assumed that the inhibition of NADH-CoQ-OxR activity in IMM of S37 observed under the influence of SDA is followed by the enhancement of ROS formation by this enzyme. It is also assumed that a decrease of CO activity in IMM of S37 induced by SDA administration occurs due to the inhibition of enzyme as a result of modification of $\mathrm{CO}$ active site with free radicals which amount increases in S37 under the influence of SDA [20].

The obtained results indicate the inhibition of NADH-CoQ-oxidoreductase, succinate dehydrogenase and cytochrome oxidase in tumor IMM under the influence of SDA. On the other hand, the data described in [2,33] give the evidence that the selective inhibition of SDH activity by malonate stimulates the generation of ROS in the complexes I and III of respiratory chain of IMM and the use of rotenone induces the generation of ROS in the complex I. It could be assumed that the increase of lipid peroxidation intensity in IMM of S37 observed previously under the influence of SDA [20] might be correlated with the decrease of activity of the respiratory chain complexes.

SDA facilitates the increase of ROS formation intensity in S37 that is confirmed by the observed increase of the value of the luminescence of lucigenin which penetrated into S37 cells [34]. Besides, the administration of SDA leads to the increase of $\mathrm{H}_{2} \mathrm{O}_{2}$-induced lucigenin luminescence that testifies the increment of intensity of integral prooxidant processes. And a higher level of accumulation of thiobarbituric acid reactive substances is the characteristic property for IMM isolated from S37 of SDA-treated mice [20]. The stationary phase of S37 growth is characterized by intensification of lipid peroxidation in S37 tumors, particularly in mitochondria compared with S37 in the exponential phase of growth.

The obtained results are in accordance with the data on the mechanism of SDA action that is characterized by the increased generation of superoxideanion (that is toxic towards the biomacromolecules including nucleic acids, the functional groups of enzymes and the protein-lipid complexes) by mito- 
chondria of tumor cells under the influence of SDA [4]. An increase in the content of free radicals in the microenvironment of tumor cells accompanies the metabolic stress, inflammation in tumor focus and could be a result of tumor cells death from apoptosis or necrosis [2, 3]. The changes of the functional activity of respiratory chain enzymes might be caused by alterations of physical and dynamical properties of IMM that could be possibly changed due to the enhanced lipid peroxidation. The decrease of the value of tryptophanyl fluorescence intensity for IMM of tumor with S37 growth and under SDA influence could be due to the structural rearrangements of IMM proteins accompanied with the transition of tryptophanyl residues into more hydrophobic surroundings. The gradual decrease of $K_{\mathrm{q}}$ value with tumor growth and under SDA influence gives the evidence of the increase of conformational rigidity of protein molecules of IMM from S37.

The growth of S37 is accompanied by modification of protein molecules of IMM from tumor cells and that leads to a reduced intramolecular dynamics of protein molecules and to decrease of tryptophanyl residues fluorescence. These changes in S37 are amplified after the administration of SDA to tumorbearing mice that could be caused by the modification of the structure of proteins by the excessive amounts of reactive oxygen species which content increases in S37 cells under SDA action. The latter statement finds the confirmation in our data that were obtained preliminarily for S37 of SDA-treated and untreated mice and pointed out the increase of the content of secondary lipid peroxidation products in IMM of tumors under the substance influence.

Relatively stable rate of microviscosity of tumor IMM lipid phase with tumor growth could be explained by changes in the properties of lipid components just at the beginning of the active tumor growth.

The tendency for a decrease of total lipid phase and annular lipids microviscosity is observed for IMM from S37 of SDA-treated animals at the exponential phase of tumor growth compared with IMM from tumors of untreated mice. It is known, on the one hand, that microviscosity of lipid bilayer depends on the phospholipid composition, content of cholesterol which organizes the structure of membrane, content of unsaturated fatty acids, and intensity of lipid peroxidation [19]. On the other hand, the enchancement of lipid peroxidation within the mem- brane is accompanied by a decrease of lipid phase microviscosity [35] that allows one to assume the coupling of the detected changes of tumor IMM lipid phase dynamic properties with intensification of lipid peroxidation in mitochondria membranes after the influence of SDA.

The use of SDA did not affect the degree of tumor IMM proteins immersion into the lipid bilayer, but the obtained results suggest that with S37 growth the immersion of proteins in the lipid matrice of IMM decreases.

The differences in the superficial properties of IMM of S37 of SDA-treated and untreated mice detected using fluorescent probe ANS could be explained as a result of possible modification of lipid component in the area of polar "heads" and glycerol residues of phospholipid molecules and hydrophylic areas of IMM proteins. These changes indicate the possibility of local rearrangements of IMM in the sites of ANS binding, their molecular environment and polarity of adjacent areas.

So, with S37 growth the intensification of glycolytic metabolism on the background of suppressed functional ability of enzymes within the respiratory chain occurs. The accumulation of lipid peroxidation products in S37 cells, particularly in mitochondria membrane, especially at the stationary phase of tumor growth, was shown [20]. The insufficiency of antioxidant enzymes demonstrated for growing S37 [20] leads to the manifestation of ROS-induced effects among which the changes of conformational properties of protein molecules and the increase of IMM lipid phase microviscosity exist.

The administration of sodium dichloroacetate promotes the formation of pyruvate and its transformation by piruvate dehydrogenase complex in S37. That leads to the increased electrone flux in mitochondria resulting in amplifying of ROS generation by the functionally suppressed complexes of IMM respiratory chain. The consequences of reactive oxygen species accumulation in S37 cells are the increase of IMM bulk and total lipid phase microviscosity and the changes of conformational stability of protein molecules within the mitochondria membrane of S37.

Taking into account the data given in the literature it could be assumed that the changes in the metabolic state of S37 induced by the administration of sodium dichloroacetate into tumor-bearing mice might be considered to be in the relation with the mechanism of SDA antitumor effect. 


\section{ФУНКЦІОНАЛЬНИЙ І ДИНАМІЧНИЙ СТАН ВНУТРІШНЬОЇ МЕМБРАНИ МІТОХОНДРІЙ САРКОМИ 37 У МИШЕЙ ЗА ВВЕДЕННЯ ДИХЛОРАЦЕТАТУ НАТРІЮ}

\section{С. В. Хижняк', Л. В. Сорокіна ${ }^{2}$,} Л. I. Степанова ${ }^{3}$, О. А. Капля ${ }^{4}$

${ }^{1}$ Національний університет біоресурсів і природокористування України, Київ; e-mail: khs2014@ukr.net;

2ІІнститут експериментальної патології, онкології та радіобіології ім. Р. Є. Кавецького НАН України, Київ; ${ }^{3}$ ННЦ «Інститут біології», Київсьий національний університет імені Тараса Шевченка, Україна;

${ }^{4}$ Інститут біохімії ім. О. В. Палладіна НАН України, Київ

Досліджено активність ензимів дихального ланцюга та структурно-динамічні властивості внутрішньої мембрани мітохондрій (BMM) саркоми 37 (С37) у мишей за введення дихлорацетату натрію в щоденній дозі 86 мг/кг маси тіла від 2-го дня після перещеплення пухлини. Динамічний і структурний стан компонентів ВММ оцінювали за допомогою флуоресцентних зондів. 3 ростом С37 відбувалася інтенсифікація гліколітичного метаболізму на тлі пригніченої функціональної здатності ензимів дихального ланцюга мітохондрій. Показано конформаційні зміни протеїнових молекул і мікров'язкості ліпідної фази ВММ. Введення дихлорацетату натрію мишам із С37 зменшувало вміст лактату в пухлині та підвищувало активність піруватдегідрогенази. Це супроводжувалось подальшим зниженням функціональної активності комплексів дихального ланцюга та активності $\mathrm{H}^{+}$АТРази поряд із конформаційною модифікацією протеїнових молекул та змінами структурної впорядкованості ліпідної компоненти ВММ, що можливо пов'язано із інтенсифікацією утворення активних форм кисню в С 37.

К л ю ч о в і с л о в а: саркома 37, дихлорацетат натрію, гліколіз, внутрішня мембрана мітохондрій, ензими дихального ланцюга, мікров'язкість ліпідної фази, конформаційний стан протеїнів.

\section{ФУНКЦИОНАЛЬНОЕ И ДИНАМИЧЕСКОЕ СОСТОЯНИЕ ВНУТРЕННЕЙ МЕМБРАНЫ МИТОХОНДРИЙ САРКОМЫ 37 У МЫШЕЙ ПРИ ВВЕДЕНИИ ДИХЛОРАЦЕТАТА НАТРИЯ}

\author{
С. В. Хижняк', Л. В. Сорокина ${ }^{2}$, \\ Л. И. Степанова ${ }^{3}$, А. А. Капля ${ }^{4}$
}
${ }^{1}$ Национальный университет биоресурсов и природопользования Украины, Киев; e-mail: khs2014@ukr.net;
${ }^{2}$ Институт экспериментальной патологии, онкологии и радиобиологии им. Р. Е. Кавецкого НАН Украины, Киев; ЗуУНЦ «Институт биологии», Киевский национальный университет имени Тараса Шевченко, Украина;
${ }^{4}$ Институт биохимии им. А. В. Палладина НАН Украины, Киев

Исследована активность энзимов дыхательной цепи и структурно-динамические свойства внутренней мембраны митохондрий (BMM) саркомы 37 (С37) у мышей при введении дихлорацетата натрия в ежедневной дозе 86 мг/кг массы тела, начиная со 2-го дня после перевивки опухоли. Динамическое и структурное состояние компонентов ВММ оценивали с помощью флуоресцентных зондов. По мере роста С 37 происходила интенсификация гликолитического метаболизма на фоне угнетенной функциональной способности энзимов дыхательной цепи митохондрий. Показаны изменения конформационных свойств протеиновых молекул и микровязкости липидной фазы ВММ. Введение дихлорацетата натрия мышам с С37 уменьшало содержание в опухоли лактата и увеличивало активность пируватдегидрогеназы. Это сопровождалось снижением функциональной активности комплексов дыхательной цепи и активности $\mathrm{H}^{+}$-АТРазы наряду с конформационной модификацией протеиновых молекул и изменениями структурной упорядоченности липидного компонента ВММ, что, возможно, связано с интенсификацией образования активных форм кислорода.

К л ю ч е в ы е с л о в а: саркома 37, дихлорацетат натрия, гликолиз, внутренняя мембрана митохондрий, энзимы дыхательной цепи, микровязкость липидной фазы, конформационное состояние протеинов. 


\section{References}

1. Brahimi-Horn M. C., Bellot G., Pouysségur J. Hypoxia and energetic tumour metabolism. Curr. Opin. Genet. Dev. 2011;21(1):67-72.

2. Turrens J. F. Mitochondrial formation of reactive oxygen species. J. Physiol. 2003;552(Pt 2):335344.

3. Fogg V. C., Lanning N. J., Mackeigan J. P. Mitochondria in cancer: at the crossroads of life and death. Chin. J. Cancer. 2011;30(8):526-539.

4. Michelakis E. D., Webster L., Mackey J. R. Dichloroacetate (DCA) as a potential metabolictargeting therapy for cancer. Br. J. Cancer. 2008;99(7):989-994.

5. Wong J. Y., Huggins G. S., Debidda M., Munshi N. C., De Vivo I. Dichloroacetate induces apoptosis in endometrial cancer cells. Gynecol. Oncol. 2008;109(3):394-402.

6. Archer S. L., Gomberg-Maitland M., Maitland M. L., Rich S., Garcia J. G., Weir E. K. Mitochondrial metabolism, redox signaling, and fusion: a mitochondria-ROSHIF-1alpha-Kv1.5 O2-sensing pathway at the intersection of pulmonary hypertension and cancer. Am. J. Physiol. Heart. Circ. Physiol. 2008;294(2):H570-H578.

7. McMurtry M. S., Bonnet S., Wu X., Dyck J. R., Haromy A., Hashimoto K., Michelakis E. D. Dichloroacetate prevents and reverses pulmonary hypertension by inducing pulmonary artery smooth muscle cell apoptosis. Circ. Res. 2004;95(8):830-840.

8. Kimura S., Ohtuki N., Nezu A., Tanaka M., Takeshita S. Clinical and radiologic improvements in mitochondrial encephalomyelopathy following sodium dichloroacetate therapy. Brain Dev. 1997;19(8):535-540.

9. Diller I. C. Cytological studies of sarcoma 37. Growth. 1952;16(2):109-125.

10. Workshop on biochemistry: a training manual. Ed. by S. E.Severin, G. A. Soloviova. M.: Moscow State University publishing house, 1989. 509 p. (In Russian).

11. Sun R. C., Fadia M., Dahlstrom J. E., Parish C. R., Board P. G., Blackburn A. C. Reversal of the glycolytic phenotype by dichloroacetate inhibits metastatic breast cancer cell growth in vitro and in vivo. Breast Cancer Res. Treat. 2010;120(1):253-260.
12. Padh H. Proceedings of the $13^{\text {th }}$ Workshop of the Association for Biology Laboratory Education (ABLE). 1992;13:129-146.

13. Sorokina L. V., Solyanik G. I., Pyatchanina T. V. The evaluation of prooxidant and antioxidant state of two variants of Lewis lung carcinoma: a comparative study. Exp. Oncol. 2010;32(4):249253.

14. Tfelt-Hansen P., Siggaard-Andersen O. Lactate and pyruvate determination in 50 mu- 1 whole blood. Scand. J. Clin. Lab. Invest. 1971;27(1):1519.

15. Hinman L. M., Blass J. P. An NADH-linked spectrophotometric assay for pyruvate dehydrogenase complex in crude tissue homogenates. J. Biol. Chem. 1981;256(13):65836586.

16. Hardy L., Clark J. B., Darley-Usmar V. M., Smith D. R., Stone D. Reoxygenation-dependent decrease in mitochondrial NADH:CoQ reductase (Complex I) activity in the hypoxic/reoxygenated rat heart. Biochem. J. 1991;274(Pt 1):133-137.

17. Cardoso S. M., Proenca M. T., Santos S., Santana I., Oliveira C. R. Cytochrome c oxidase is decreased in Alzheimer's disease platelets. Neurobiol. Aging. 2004;5(1):105-110.

18. Krause F., Reifschneider N. H., Goto S. Active oligomeric ATP synthases in mammalian mitochondria. Biochem. Biophys. Res. Commun. 2005;329:583-590.

19. Zhirnov V. V., Khyzhnyak S. V., Voitsitsky V. M. The effects of ultra-low dose beta-radiation on the physical properties of human erythrocyte membranes. Int. J. Rad. Biol. 2010;86(6):499506.

20. Sorokina L. V., Pyatchanina T. V., Didenko G. V., Kaplia A. A., Khyzhnyak S. V. The influence of sodium dichloroacetate on the oxidative processes in sarcoma 37. Exp. Oncol. 2011;33(4):216-221.

21. Stacpoole P. W., Nagaraja N. V., Hutson A. D. Efficacy of dichloroacetate as a lactate-lowering drug. J. Clin. Pharmacol. 2003;43(7):683-691.

22. Gogvadze V. G., Bruetovetskiǐ N. N., Zhukova A. A. Participation of phospholipase A2 in uncoupling in rat liver mitochondria induced by products of lipid peroxidation. Biokhimiia (Moscow). 1990;55(12):2195-2199.

23. Stacpoole P. W., Henderson G. N., Yan Z., James M. O. Clinical pharmacology and 
toxicology of dichloroacetate. Environ. Health Perspect. 1998;106(Suppl. 4):989-994.

24. Kennedy K. M., Dewhirst M. W. Tumor metabolism of lactate: the influence and therapeutic potential for MCT and CD147 regulation. Future Oncol. 2010;6(1):127-148.

25. Chen Z., Lu W., Garcid-Prieto C., Huang P. The Warburg effect and its cancer therapeutic implications. J. Bioenerg. Biomembr. 2007;39(3):267-274.

26. Heerdt B. G., Houston M. A., Augenlicht L. H. The intrinsic mitochondrial membrane potential of colonic carcinoma cells is linked to the probability of tumor progression. Cancer Res. 2005;65(21):9861-9867.

27. Briere J.-J., Benit P., Rustin P. The electron transport chain and carcinogenesis. - In: Cellular Respiration and Carcinogenesis. Ed. by S. P. Apte, R. Sarangarajan. N.Y.: Humana Press, 2009. P. 19-32.

28. Baysal B. E., Ferrell R. E., Willett-Brozick J. E., Lawrence E. C., Myssiorek D., Bosch A., van der Mey A., Taschner P. E., Rubinstein W. S., Myers E. N., Richard C. W. 3rd, Cornelisse C. J., Devilee P., Devlin B. Mutations in SDHD, a mitochondrial complex II gene, in hereditary paraganglioma. Science. 2000;287(5454):848851.

29. Simonnet H., Alazard N., Pfeiffer K., Gallou C., Béroud C., Demont J., Bouvier R., Schägger H., Godinot C. Low mitochondrial respiratory chain content correlates with tumor aggressiveness in renal cell carcinoma. Carcinogenesis. 2002;23(5):759-768.
30. Sun A. S., Sepkowitz K., Geller S. A. A study of some mitochondrial and peroxisomal enzymes in human colonic adenocarcinoma. Lab. Invest. 1981;44(1):13-17.

31. Fukuda R., Zhang H., Kim J. W., Shimoda L., Dang C. V., Semenza G. L. HIF-1 regulates cytochrome oxidase subunits to optimize efficiency of respiration in hypoxic cells. Cell. 2007;129(1):111-122.

32. Muller F. L., Roberts A. G., Bowman M. K., Kramer D. M. Architecture of the Qo site of the cytochrome bc1 complex probed by superoxide production. Biochemistry. 2003;42(21):64936499.

33. Sorokina L. V., Makovetska L. I., Didenko G. V., Ganzha O. B., Khyzhnyak S. V. The modification of prooxidant and antioxidant state of sarcoma 37 cells under using of sodium dichloroacetate. Scientific conference "Biologically active substances: fundamental and applied problems" (Novy Svet, Crimea, May 2011). P. 606.

34. Chen J. J., Yu B. P. Alterations in mitochondrial membrane fluidity by lipid peroxidation products. Free Radic. Biol. Med. 1994;17(5):411418.

35. Andreyev A. Yu., Kushnareva Yu. E., Starkov A. A. Mitochondrial metabolism of reactive oxygen species. Biochemistry (Moscow). 2005;70(2):200-214.

Received 28.01.2014 